\title{
Cellulases Production by Free and Immobilized Aspergillus flavus
}

\author{
A.S. Youssef ${ }^{1^{*}}$, M.A. Hassan ${ }^{2}$, S.M. El-Sayed ${ }^{1}$, G.E.M. \\ Elsayed $^{2}$ and S.A. El-Aassr ${ }^{1}$ \\ ${ }^{1}$ Botany and Microbiology Department, Faculty of Science and \\ Biology and Geology Department, Faculty of Education, \\ Alexandria University, Alexandria, Egypt.
}

\begin{abstract}
7 HE PRODUCTION of cellulase from some local fungal isolates was studied. The results showed that Aspergillus flavus produced the highest cellulase activity $(3.017 \mathrm{U} / \mathrm{ml})$ under static condition. It also showed that the best carbon source for cellulase production was filter papers $(7.0932 \mathrm{U} / \mathrm{ml})$, and onion scales $(6.396$ $\mathrm{U} / \mathrm{ml}$ ) at a concentration $30 \mathrm{~g} / \mathrm{l}$ medium. The Plackett-Burman design was studied for cellulase production from A. flavus showed that the optimizing medium achieved by the statistical design increased cellulase activity $(11.699 \mathrm{U} / \mathrm{ml})$ which approximately 2.3 times than that obtained from the basal medium. In addition, A. flavus biomass was entrapped in different gel materials, and the best one for producing cellulase was agar $(8.22 \mathrm{U} / \mathrm{ml})$, however, this activity was lower than that in free cultures. Moreover, A. flavus biomass was adsorbed on different porous materials, and the cultures adsorbed on luffa pulp exerted the highest cellulase activity $(17.78 \mathrm{U} / \mathrm{ml})$ which was higher than that produced by free cultures. By reusing the adsorbed A. flavus biomass on luffa pulp in seven successive times, the $4^{\text {th }}$ cycle gave the highest cellulase activity $(34.17 \mathrm{U} / \mathrm{ml})$. It was concluded that A. flavus is a feasible candidate for the production of cellulase activity which can be applied in many industrial fields. The results also indicate the possibility of using different agro-wastes like onion scales as a sole carbon source for production of cellulase by $A$. flavus.
\end{abstract}

Keywords: Aspergillus flavus, Cellulase, Plackett-Burman design, Adsorption.

Cellulose is an organic polysaccharide compound with the formula $\left(\mathrm{C}_{6} \mathrm{H}_{10} \mathrm{O}_{5}\right)_{\mathrm{n}}$. It consists of a linear chain of several hundred to over ten thousand $\beta(1 \rightarrow 4)$ linked D-glucose units (Crawford, 1981). Cellulose is the structural component of the primary cell wall of green plants, many forms of algae, and the Oomycetes. About $33 \%$ of all plant matter is cellulose, the cellulose content of cotton is $90 \%$ and that of wood is 40-50\% (Klemn et al., 2005).

Cellulolytic enzymes are formed by a large number of microorganisms. Cellulolytic microorganisms are found amongst fungi, actinomycets and bacteria. Native cellulose is enzymatically hydrolyzed by a group of enzymes

*Corresponding author: Amany S. Youssef

E-mail: amanyyoussef70@yahoo.com 
(endo-B-glucanases, and exo-B-glucanases) acting synergistically. The celluloytic enzyme systems of distinct microorganisms are often different. Only true cellulolytic organisms possessing exoglucanase activity can hydrolyse native cellulose. Fungi are the major group of organisms responsible for cellulose degradation, possibly accounting for as $80 \%$ of global cellulolysis (Markham and Bazin, 1991). Fungi are generally 50-1000 times more cellulolytic than the most active bacteria (Saddler et al., 1984). A. flavus has been reported as one of these fungi (Ojumu et al., 2003).

Although a large number of microorganisms are capable of degrading cellulose, only few of them produce significant quantities of cell free cellulase capable of completely hydrolyzing crystalline cellulose in vitro (Jungebloud et al., 2007). Species of Aspergillus are well known and efficient producers of plant cell wall degrading enzyme system (Oksanen et al., 2000; Coral et al., 2002; Onsori et al., 2005). The work on cellulase production by Aspergillus species has been conducted all over the world. However, the physiological responses of different species may vary with ecological variations.

In the search for good producers of cellulolytic enzymes, however, only relatively few fungal species have been selected by various research workers. Such fungi are: Aspergillus nidulans (Lee et al., 1989), A. niger (Gokhaled et al., 1991), Chaetomium globosum (Lakshmikant and Mathur, 1990). Fusarium oxysporum (Orteg, 1990), Neurospora crassa (Yazdi et al., 1990), Penicillium verruculosum (Chung et al., 1982), Pleurotu spp (Hong et al., 1988), Trichoderma koningii G-39 (Huang and Forsberg, 1990), T. pseudokningii S-38 (Ma et al., 1990), and Trichoderma sp.A.001 (Gashe, 1992).

The saccharification of different agro-wastes has been reported by other workers employing enzymes from different organisms. Vlasenko et al. (1993) investigated 30 potential cellulosic raw materials for saccharification by Penicillium cellulases. Farooq et al. (1994) studied the saccharification of Kallar grass straw with thermostable cellulases from several fungi including Chaetomium thermophile, Trichoderma reseei, Sporotrichum thermophile, Aspergillus fumigatus, Torula thermophila and Humicola grisea. Okeke and Obi (1995) reported the saccharification of agro-wastes by cellulases and hemicellulases from two fungal isolates viz. Sporotrichum pruinosum and Arthrographis sp., while Castellanos et al., (1995) evaluated various hydrolysis conditions of skop, short fiber waste material from paper industry and cellulosic material by cellulolytic enzymes of fungi.

Recent interest has been focused on the search for new and cheap renewable raw materials for the production of cellulolytic enzymes. On the other hand, the search for new microorganisms capable of producing cellulolytic enzymes suitable for saccharifying these cellulosic wastes is also of potential importance in Egypt. Therefore, the present study aimed to investigate the direct utilization 
of different cellulose-containing waste products by free and immobilized Aspergillus cells for the production of celluase enzyme.

\section{Material and Methods}

\section{Microorganisms}

In the present work, four fungi were isolated from soil in the garden of Faculty of Science, Alexandria University, and Shalalate Municipal garden, Alexandria, Egypt. Fungi were cultured in the first screening experiments on Dox-medium which was also used for maintenance of the fungal isolates throughout the work. This medium contained the following ingredients $(\mathrm{g} / \mathrm{l})$ $\mathrm{NaNO}_{3}, 1 ; \mathrm{K}_{2} \mathrm{HPO}_{4}, 1 ; \mathrm{MgSO}_{4} .7 \mathrm{H}_{2} \mathrm{O}, 0.5 ; \mathrm{NaCl}, 0.01$; cellulose, 20 (filter paper soaked over night then crashed), agar, 20; and the final $\mathrm{pH}$ was adjusted to 5.0. The isolated fungi were kindly identified by the Mycological Center, Assiut University, Egypt according to the regulations and keys described by Domsch et al. (2007). The isolated fungi were Aspergillus flavus, Aspergillus niger, Aspergillus fumigatus, and Penicillium sp.

\section{Natural carbon sources}

The effect of carbon source on the production of cellulase was studied using the basal culture medium supplemented with filter papers as a control. On the other experiments, filter papers were replaced by equal amounts of different carbon sources which were untreated onion scales, treated onion scales (decolorized by $5 \%$ sodium hypochlorite, washed by distilled water several times, dried, and cut into very small pieces), garlic scales, saw dust, carboxymethylcellulose (CMC), bagasse, and cellulose powder. Each carbon source was supplemented separately on each flask, one at a time. Different concentrations of onion scales ranging from 5 to $40 \mathrm{~g} / 50 \mathrm{ml}$ were individually supplemented to the basal medium to study the effect of onion scales concentration on the growth and cellulase activity of A. flavus.

\section{Cultivation of A. flavus for cellulase production}

Fifty $\mathrm{ml}$ aliquots of the Dox's meduim were dispensed in $250 \mathrm{ml}$ Erlenmeyer flasks. The medium was adjusted to $\mathrm{pH} 5$ and then sterilized at $121^{\circ} \mathrm{C}$ for $15 \mathrm{~min}$. After sterilization, each flask was inoculated with $1 \mathrm{ml}$ fungal spore suspension, obtained from 7 days old slant culture. The flasks were then incubated statically at $28^{\circ} \mathrm{C}$ for 7 days. Thereafter, the culture filtrate of each flask was taken for analysis. Each treatment was carried out in triplicates and the results obtained throughout the work were the arithmetic mean of the three experiments.

Preparation of crude enzyme, estimation of soluble protein, and assay of cellulase activity

At the end of the incubation period, A. flavus cells were separated from the culture by filtration using filter paper, and the clear supernatant was considered as the crude enzyme source. The protein content of the enzyme preparation was 
determined by the method of Lowry et al. (1951). Cellulase activity was measured according to the method of Miller (1959).

\section{Plackett-Burman design}

The design of Plackett and Burman (1946) was used in this study to reflect the relative importance of various fermentation factors on the activity of cellulase for degradation of cellulose. In this experiment, seven independent variables were screened in eight combinations organized according to the Plackett-Burman design. For each variable, a high (+) and low (-) level was tested. All trails were performed in duplicates and the average results were treated as the responses. The main effect of each variable was determined with the following equation: $\mathrm{E}_{\mathrm{xi}}=\left(\Sigma \mathrm{M}_{\mathrm{i}+}-\Sigma \mathrm{M}_{\mathrm{i}-}\right) / \mathrm{N}$ Where $\mathrm{E}_{\mathrm{xi}}$ is the variable main effect, $\mathrm{M}_{\mathrm{i}+}$ and $\mathrm{M}_{\mathrm{i}-}$ are the activity percentage in trails where the independent variable (xi) was present in high and low concentrations, respectively, and $\mathrm{N}$ is the number of trials divided by 2 . A main effect figure with a positive sign indicates that the high concentration of this variable is near to the optimum and a negative sign indicates that the low concentration of this variable is near to the optimum. Using Microsoft Excel, statistical t-values for equal unpaired samples were calculated for determination of variable significance.

\section{Immobilization of A. flavus cells by gel entrapment}

This experiment investigated the extracellular cellulase production by $A$. flavus biomass that was entrapped in alginate and agar using free cells as a control. An optimized culture medium in $250 \mathrm{ml}$ Erlenmeyer flasks was introduced to porous beads of gel material including fungal cells. After 7 days in static culture at $28^{\circ} \mathrm{C}$, the cellulase activity and protein content of the culture filtrate were determined for the entrapped and free cells. Fungal cells were entrapped in $2 \%$ calcium alginate gel beads according to the procedure described by Eikmerier et al. (1984). Also, entrapment in agar was done as mentioned by Chapatwala et al. (1993).

\section{Immobilization of A. flavus cells by adsorption}

Five $\mathrm{ml}$ of fungal cell suspension was added to the Erlenmeyer flask $(250 \mathrm{ml})$ containing sterilized culture medium $(25 \mathrm{ml})$ containing sponge cubes, luffa, ceramic, stainless steel, clay particles, and pumice which were washed several times with water before use. These flasks were then placed in static incubator at $28^{\circ} \mathrm{C}$ for 7 days.

Semi-continuous cellulase production by adsorbed A. flavus on luffa pulp

The effect of reusing of entrapped A. flavus mycelia on the production of cellulase using luffa pulp as a porous supporter polymer was investigated. The experiment was carried out by batch wise reuse of the entrapped mycelia. At the end of each reuse the culture media were decanted and fresh media were added under aseptic conditions to the entrapped fungus. The time interval for the reuse was 7 days. Incubation was carried out at $28^{\circ} \mathrm{C}$.

Egypt. J. Bot., 54, No. 1 (2014) 
Scanning electron microscopy

The adsorbent fungal mycelia were scanned using electron microscope. This was done in the Electron Microscope Unit in Faculty of Sceince, Alexandria University.

\section{Results}

Production of extracellular cellulase by the fungal isolates

The results in Table 1 indicate that all the tested isolates from the Dox's medium were able to degrade cellulose and produce extracellular cellulase under static and shaken conditions with different levels. A. flavus produced the highest extracellular cellulase activity $(3.017 \mathrm{U} / \mathrm{ml})$, followed by $A$. niger $(2.89 \mathrm{U} / \mathrm{ml}), A$. fumigatus $(1.717 \mathrm{U} / \mathrm{ml})$, and Penicillium $(1.299 \mathrm{U} / \mathrm{ml})$. Furthermore, the extracellular cellulase activity detected in culture filtrates of agitated culture after 7-day incubation period was generally lower than that of static culture, where cellulase activity obtained from $A$. flavus was $(1.73 \mathrm{U} / \mathrm{ml})$, followed by $A$. niger $(1.19 \mathrm{U} / \mathrm{ml})$, A. fumigatus $(0.50 \mathrm{U} / \mathrm{ml})$, and Penicillium $(0.025 \mathrm{U} / \mathrm{ml})$. Therefore, A. flavus cultivated under static condition was selected for the production of extracellular cellulase for further study.

TABLE 1. Production of extracellular cellulase by some local fungi in static and agitated cultures.

\begin{tabular}{|l|c|c|c|c|}
\hline \multirow{2}{*}{ Microorganisms } & \multicolumn{2}{|c|}{ Static culture } & \multicolumn{2}{c|}{ Agitated culture } \\
\cline { 2 - 5 } & $\begin{array}{c}\text { Protein } \\
\text { content } \\
\text { (mg/ml) }\end{array}$ & $\begin{array}{c}\text { Cellulase } \\
\text { activity } \\
(\mathbf{U} / \mathrm{ml})\end{array}$ & $\begin{array}{c}\text { Protein } \\
\text { content } \\
(\mathrm{mg} / \mathrm{ml})\end{array}$ & $\begin{array}{c}\text { Cellulase } \\
\text { activity } \\
(\mathrm{U} / \mathrm{ml})\end{array}$ \\
\hline \multirow{2}{*}{ Aspergillus flavus } & 0.586 & 3.017 & 0.425 & 1.73 \\
Aspergillus niger & 0.587 & 2.89 & 0.472 & 1.19 \\
Aspergillus fumigatus & 0.413 & 1.717 & 0.146 & 0.50 \\
Penicillium sp. & 0.428 & 1.299 & 0.433 & 0.025 \\
& & & & \\
\hline
\end{tabular}

Effect of natural substrates as carbon sources

The data in Fig.1 show that the filter papers was the most preferable carbon source yielding a maximal cellulase activity $(7.093 \mathrm{U} / \mathrm{ml})$, followed by treated onion scales $(5.697 \mathrm{U} / \mathrm{ml})$. On the other hand, the lowest cellulase activity was obtained in cultures containing bagasse, and cellulose powder. 


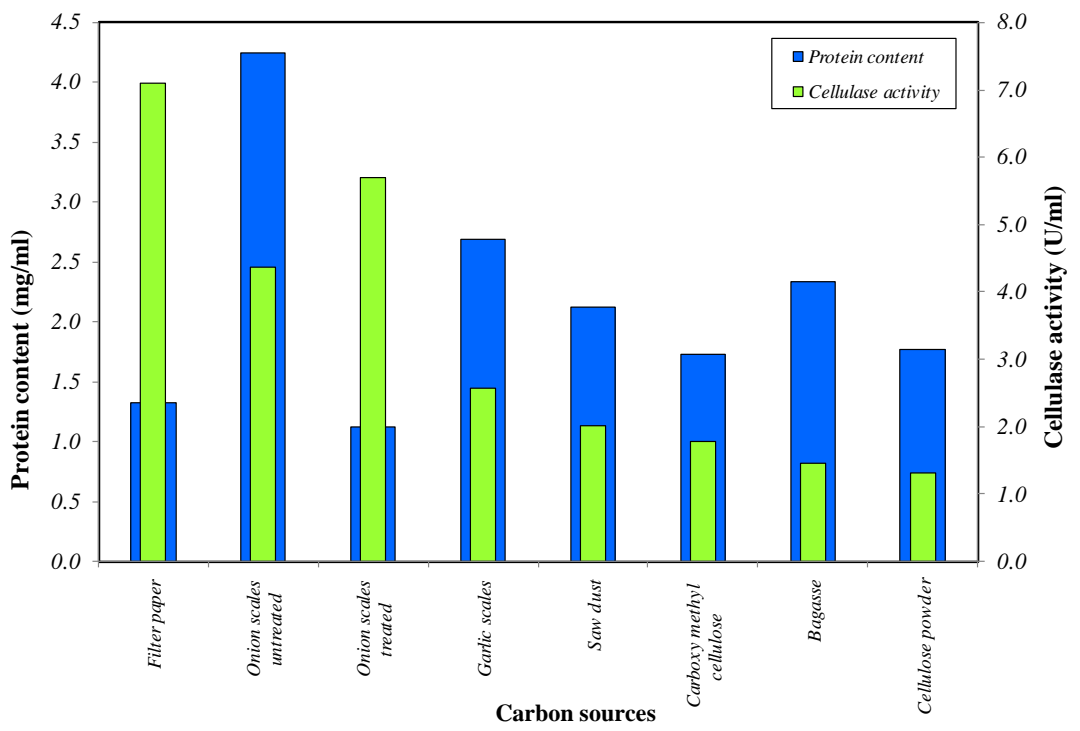

Fig. 1. Effect of some natural substrates as carbon sources on the production of cellulase in A. flavus cultures.

Effect of different concentrations of onion scales

The results in Table 2 indicate that the optimum concentration of onion scales was $30 \mathrm{~g} / \mathrm{L}$, which yielded the highest cellulase activity $(6.396 \mathrm{U} / \mathrm{ml})$, as well as higher specific activity.

TABLE 2. Effect of different concentration of onion scales on the production (activity) of cellulase from $A$. flavus

\begin{tabular}{|c|c|c|c|}
\hline $\begin{array}{c}\text { Onion scales } \\
\text { concentration } \\
(\mathbf{g} / \mathbf{5 0} \mathbf{~ m l})\end{array}$ & $\begin{array}{c}\text { Protein content } \\
(\mathbf{m g} / \mathbf{m l})\end{array}$ & $\begin{array}{c}\text { Cellulase activity } \\
(\mathbf{U} / \mathbf{m l})\end{array}$ & $\begin{array}{c}\text { Specific } \\
\text { activity } \\
(\mathbf{U} / \mathbf{m g})\end{array}$ \\
\hline 5 & 0.744 & 3.145 & 4.22 \\
10 & 0.999 & 4.028 & 4.03 \\
20 & 1.1235 & 5.697 & 5.07 \\
30 & 1.17 & 6.396 & 5.46 \\
40 & 2.275 & 4.595 & 2.01 \\
\hline
\end{tabular}

Fermentation factors affecting cellulase production by A. flavus

The Plackett-Burman design was applied to reflect the relative importance of various fermentation factors involved in cellulase production by A. flavus. The examined levels of seven culture variables are presented in Table 3. The design Egypt. J. Bot., 54, No. 1 (2014) 
was applied with nine different fermentation conditions as shown in Table 4. All experiments were performed in duplicates and the averages of results of cellulase activity $(\mathrm{U} / \mathrm{ml})$ and protein content $(\mathrm{mg} / \mathrm{ml})$ are presented in Table 5.

The principal statistical analysis of this experiment is shown in Table 6. The main effect of each variable upon enzyme production as well as protein content was estimated and presented graphically in Fig. 2 which indicated that the presence of high levels of filter papers, $\mathrm{K}_{2} \mathrm{HPO}_{4}$, and inoculum size (ml) the growth medium affect cellulase production by A. flavus positively. On the other hand, the same figure suggests that the presence of $\mathrm{MgSO}_{4}, \mathrm{FeSO}_{4}$, peptone and culture volume $(\mathrm{ml})$ at their lowest levels would result in high cellulase activity.

The results point out that high level of filter paper, inoculum size and peptone, $\mathrm{K}_{2} \mathrm{HPO}_{4}, \mathrm{MgSO}_{4}$ and $\mathrm{FeSO}_{4}$ in the medium with low levels of culture volume induced high protein content in the culture filtrate of the fungal cells.

Figure. 3 shows that the cellulase activity reached $11.699 \mathrm{U} / \mathrm{ml}$ by using the optimized medium, which is higher than that obtained from the basal medium $(7.087 \mathrm{U} / \mathrm{ml})$. Moreover, the protein content of the culture filtrates of the optimized medium increased than the basal the medium.

TABLE 3. Factors examined as independent variables and their levels in PlackettBurman experiment

\begin{tabular}{|c|c|c|c|c|}
\hline \multirow{2}{*}{$\begin{array}{c}\text { Factors } \\
\text { (g/l) }\end{array}$} & \multirow{2}{*}{ symbol } & \multicolumn{3}{|c|}{ Level } \\
\cline { 3 - 5 } & & $\mathbf{- 1}$ & $\mathbf{0}$ & $\mathbf{+ 1}$ \\
\hline FeSo4 & $\mathrm{Fe}$ & 0.0 & 0.001 & 0.01 \\
$\mathrm{~K}_{2} \mathrm{Hpo} 4$ & $\mathrm{~K}_{2}$ & 0.5 & 1 & 1.5 \\
Filter paper & $\mathrm{Fp}$ & 10 & 20 & 30 \\
MgSo4 & $\mathrm{Mg}$ & 0.1 & 0.5 & 1 \\
Peptone & $\mathrm{P}$ & 1 & 3 & 5 \\
Inoculum size $(\mathrm{ml})$ & $\mathrm{Is}$ & 1 & 3 & 5 \\
Culture volume $(\mathrm{ml})$ & $\mathrm{CV}$ & 25 & 50 & 75 \\
\hline
\end{tabular}


TABLE 4. The Plackett-Burman experimental design for seven factors

\begin{tabular}{|c|c|c|c|c|c|c|c|}
\hline \multirow{2}{*}{ Trials } & \multicolumn{7}{|c|}{ Independent variable } \\
\cline { 2 - 8 } & $\mathbf{F e}$ & $\mathbf{K}_{\mathbf{2}}$ & $\mathbf{F p}$ & $\mathbf{M g}$ & $\mathbf{P}$ & $\mathbf{I s}$ & $\mathbf{C v}$ \\
\hline 1 & -1 & -1 & -1 & 1 & 1 & 1 & -1 \\
3 & 1 & -1 & -1 & -1 & -1 & 1 & 1 \\
4 & -1 & 1 & -1 & -1 & 1 & -1 & 1 \\
5 & 1 & 1 & -1 & 1 & -1 & -1 & -1 \\
6 & -1 & -1 & 1 & 1 & -1 & -1 & 1 \\
7 & -1 & -1 & 1 & -1 & 1 & -1 & -1 \\
8 & 1 & 1 & 1 & -1 & -1 & 1 & -1 \\
9 & 0 & 0 & 0 & 0 & 0 & 0 & 0 \\
\hline
\end{tabular}

TABLE 5. Production of cellulase activity in the Plackett-Burman design of A. flavus.

\begin{tabular}{|c|c|c|c|}
\hline Trials & \multicolumn{1}{|l|}{$\begin{array}{l}\text { Cellulase } \\
\text { activity }(\mathbf{U} / \mathbf{m l})\end{array}$} & $\begin{array}{l}\text { Protein } \\
(\mathbf{g} / \mathbf{m l})\end{array}$ & $\begin{array}{l}\text { Specific activity } \\
(\mathbf{U} / \mathbf{m g} \text { protein })\end{array}$ \\
\hline 1 & 3.017024 & 1.31716 & 1.1584 \\
3 & 5.69704 & 2.49724 & 0.5784 \\
4 & 1.44432 & 1.06982 & 7.2903 \\
5 & 7.799328 & 1.3579 & 3.1921 \\
6 & 4.33296 & 2.46893 & 1.2285 \\
7 & 3.033072 & 1.9966 & 5.8839 \\
8 & 11.747136 & 2.81461 & 1.1403 \\
9 & 3.2096 & 1.97425 & 3.5868 \\
\hline
\end{tabular}

Egypt. J. Bot., 54, No. 1 (2014) 
TABLE 6. Statistical analysis of the Plackett-Burman experiment.

\begin{tabular}{|l|c|c|}
\hline \multirow{2}{*}{ Variable } & \multicolumn{2}{|c|}{ Cellulase activity (U/ml) } \\
\cline { 2 - 3 } & Main effect & t-value \\
\hline $\mathrm{FeSO}_{4}$ & -0.201 & -0.33 \\
\hline $\mathrm{K}_{2} \mathrm{HPO}_{4}$ & +2.03 & +1.25 \\
\hline Filter paper & +1.09 & +0.29 \\
\hline $\mathrm{MgSO}_{4}$ & -0.89 & -0.08 \\
\hline Peptone & -4.724 & -2.43 \\
\hline Inoculum size & +1.765 & +0.63 \\
\hline Culture volume & -2.729 & -1.7 \\
\hline
\end{tabular}

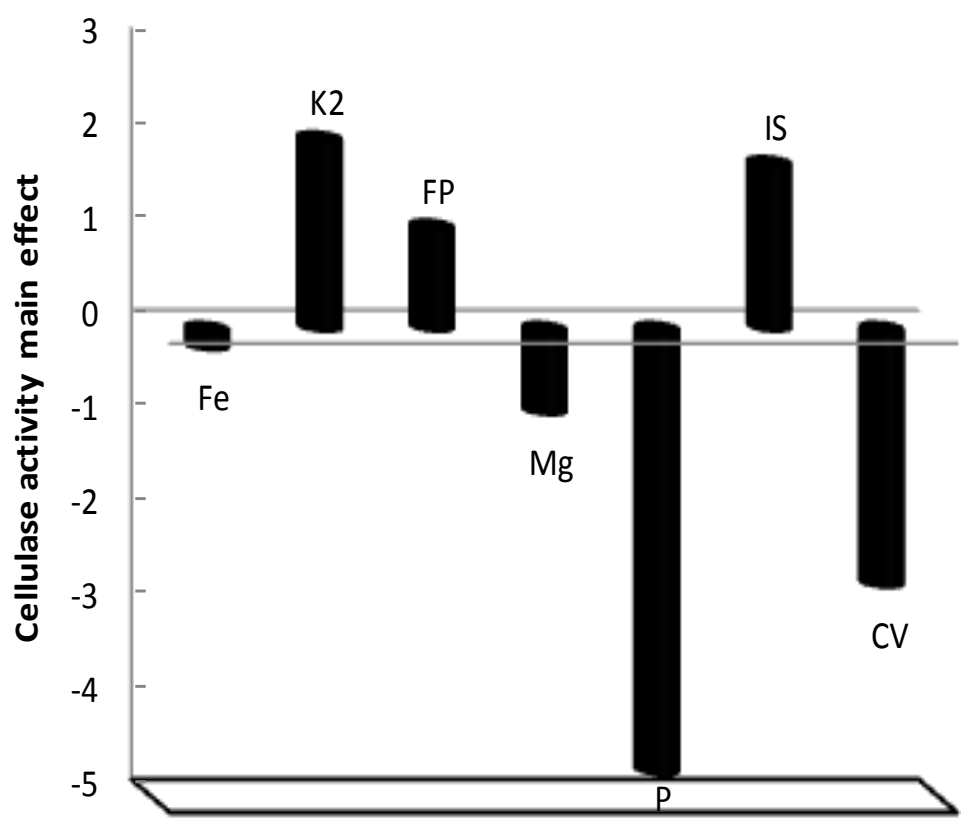

Factor

Fig. 2. Elucidation of fermentation factors affecting on enzyme activity (U/ml). 


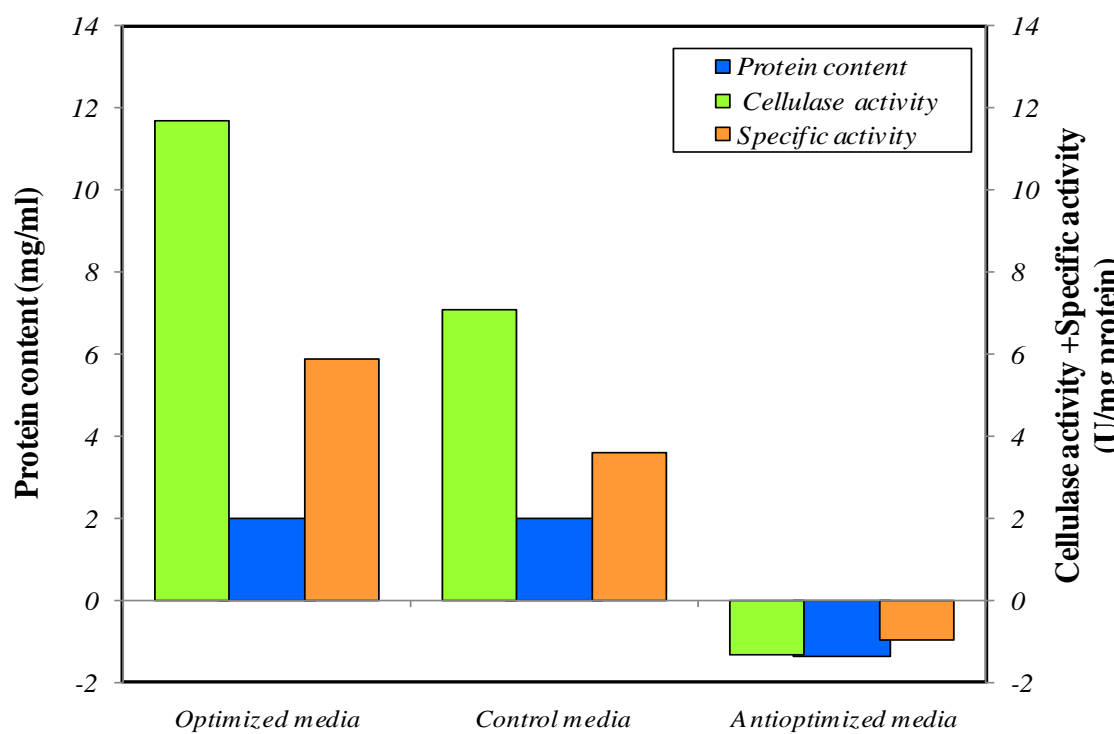

Flasks

Fig. 3. Production of cellulase from A. flavus in optimized media, anti-optimized media, and control media.

Effect of entrapping A. flavus cells with different materials on cellulase production

Table 7 shows that cellulase activity with free cells was higher than that of entrapped cells $(11.22 \mathrm{U} / \mathrm{ml})$. The agar entrapped cells recorded higher cellulase activity $(8.22 \mathrm{U} / \mathrm{ml})$ than alginate entrapped cells $(7.86 \mathrm{U} / \mathrm{ml})$.

TABLE 7. Production of cellulase by A. flavus entrapped in different gel materials.

\begin{tabular}{|l|c|c|}
\hline Gel material & Protein content $(\mathbf{m g} / \mathbf{m l})$ & Cellulase activity(U/ml) \\
\hline Alginate & 1.873 & 7.86 \\
\hline Agar & 1.52 & 8.22 \\
\hline Free cells & 1.92 & 11.22 \\
\hline
\end{tabular}

Effect of adsorption of A. flavus on cellulase production

Table 8 shows high cell adsorption on all the used supports. However, the protein content of adsorbed cultures was slightly lower than that of free cultures. Cultures containing adsorbed mycelia on luffa pulp, sponge cubes, ceramic, pumice and stainless steel metal showed higher cellulase activity, while culture containing clay pieces showed lower cellulase activity as compared to the free cells. On other hand, cultures containing luffa pulp as a solid support exhibited the highest cellulase activity $(17.78 \mathrm{U} / \mathrm{ml})$, with specific activity of $(10.58 \mathrm{U} / \mathrm{mg})$.

Egypt. J. Bot., 54, No. 1 (2014) 
TABLE 8. Production of cellulase by A. flavus adsorbed on different solid porous supports

\begin{tabular}{|l|c|c|c|}
\hline Solid support & $\begin{array}{c}\text { Protein content } \\
(\mathbf{m g} / \mathbf{m l})\end{array}$ & $\begin{array}{c}\text { Cellulase } \\
\text { activity } \\
(\mathbf{U} / \mathbf{m l})\end{array}$ & $\begin{array}{c}\text { Specific } \\
\text { activity } \\
\text { (U/mg) }\end{array}$ \\
\hline Sponge cubes & 1.56 & 14.3 & 9.16 \\
Ceramic & 1.7 & 13.05 & 7.67 \\
Clay particles & 1.48 & 7.9 & 5.33 \\
Stainless steel metal & 1.507 & 13.2 & 8.75 \\
Pumice particles & 1.72 & 13.93 & 8.09 \\
Luffa pulp & 1.68 & 17.78 & 10.58 \\
Free cells & 1.83 & 11.72 & 6.40 \\
\hline
\end{tabular}

Effect of reusing entrapped A. flavus on cellulase production

Figure 4 shows the protein content and activity of cellulase when immobilized fungal cells adsorbed on luffa pulp were re-used in seven successive times. The $4^{\text {th }}$ cycle gave high cellulase activity $(34.17 \mathrm{U} / \mathrm{ml})$ and high protein content $(2.177 \mathrm{mg} / \mathrm{ml})$. The activity decreased to the lowest value $(12.11 \mathrm{U} / \mathrm{ml})$ at the $7^{\text {th }}$ cycle with low protein content $(1.218 \mathrm{mg} / \mathrm{ml})$.

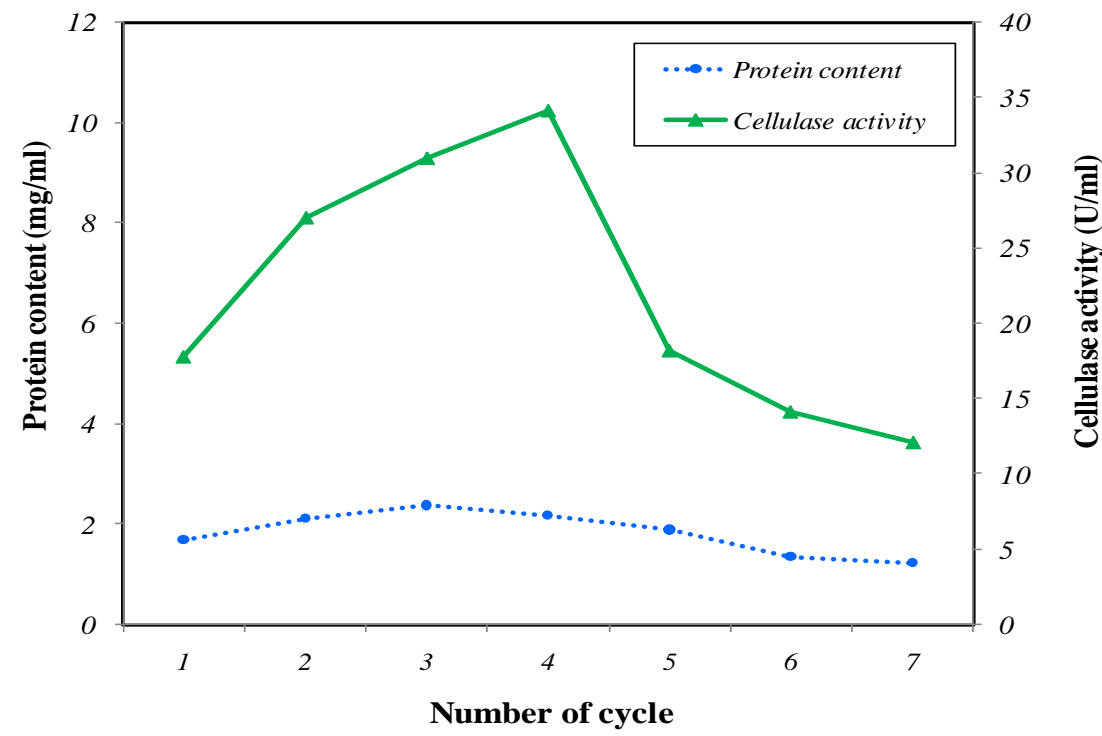

Fig. 4. Semi-continuous production of cellulase by entrapped $A$. flavus on luffa pulp. 


\section{Scanning electron micrograph}

Figure 5 shows a high condensation of fungal mycelia on luffa pulp which may explain the high activity of cellulase obtained from adsorption of $A$. flavus on luffa pulp.

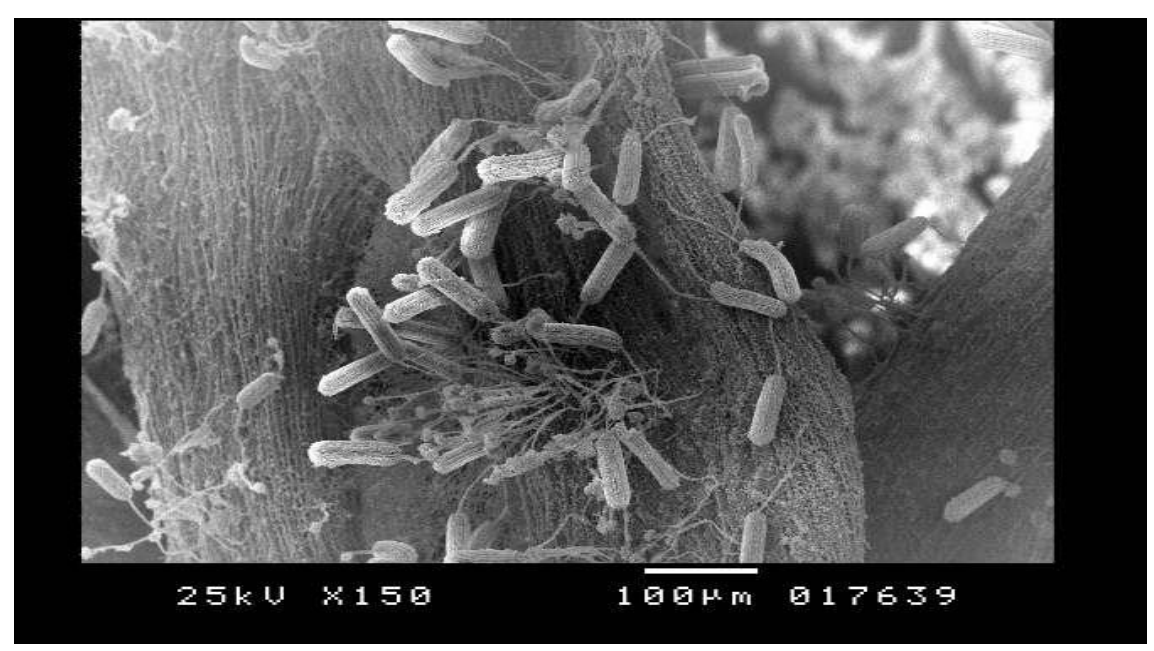

Fig. 5. Scanning electron micrograph of A. flavus adsorbed on luffa pulp.

\section{Discussion}

Cellulases have a technological importance in many industrial processes (Singh et al., 2012; Lan et al., 2013), and are very important for digestion of hemicellulose and cellulose ( $\mathrm{Li}$ et al., 2013). Cellulose is the world's most abundant natural biopolymer (Bhat, 2000), and its enzymatic hydrolysis to glucose is carried out by cellulase such as endoglucanases, cellobiohydrolases, and glycosidase (Okemoto et al., 2003). Furthermore, each of these enzymes occurs in multiple forms. Cellulose is hydrolyzed by synergistic enzymatic reactions which cause much higher activity than the simple sum of every cellulolytic enzymatic activity (Lynd et al., 2002).

The first part of the present work included a screening for the potency of some microbial isolates to produce extracellular cellulase activity. Fungi were isolated from soil in different locations using a Dox's medium contributed with cellulose as a sole carbon source. Among these isolates, A. flavus showed the highest cellulase activity under static condition. A possible explanation for the highest cellulase activity in static flask compared to the agitated flask is that, oxygen limitation could be a serious problem in the shaken flask cultivation due to the highly non-Newtonian medium that is caused by the filamentous growth of the fungus (Knapp et al., 2001).

In the present study, the effect of substitution of cellulose in the culture medium by other carbon sources, one at a time, was investigated. The maximum Egypt. J. Bot., 54, No. 1 (2014) 
cellulase activity was found when using filter papers, followed by onion scales. A low activity was found when using CMC, sawdust, and bagasse. Also, the concentration of onion scales plays an important role in cellulase production by A. flavus. It was found that the onion scales concentration of $30 \mathrm{~g} / \mathrm{l}$ was the best level for obtaining a high value of cellulase activity and protein content. Many investigators used bagasse and sawdust as a sole carbon source for the cultivation of some microorganisms. A. flavus grown on sawdust, bagasse and corncob gave low cellulase activity. The decrease in cellulase activity common to all three substrates may be due to cumulative effect of cellobiose, a dimer of glucose which is known to inhibit both endoglucanase and glycosidase (Howell, 1978). Also, Hatakka (1983) suggested that delignification produces aromatic water-soluble products which can repress the cellulolytic action of the enzyme. On the contrary, another study demonstrated high cellulase productivity from $A$. flavus with bagasse using the same operating conditions (Solomon et al., 1999). This may be due to its very high percentage of cellulose which is the major component of cell walls of wood. In another study, different carbon sources were tested for production of cellulase by Aspergillus spp. which were glucose, sucrose, cellulose, CMC, and maltose ranging from 0.5 to $3 \%(\mathrm{w} / \mathrm{v})$. Cellulose and $\mathrm{CMC}$ were found to be the best carbon sources for cellulase production by $A$. niger followed by sucrose, glucose, and maltose, while sucrose was found to be the best carbon for cellulase production by Trichoderma sp., followed by glucose, cellulose, maltose, and CMC. Cellulase production increased with increases the in initial sugar concentration, while further increases in sugar concentration slightly reduced the yield (Mandels and Reese, 1960).

In addition, the Plackett-Burman design applied in the present study for the optimization of production of the enzyme by free cells has been demonstrated as an efficient approach to screen for medium component and/or factors affecting the production of cellulase, where medium optimization is generally a timeconsuming and labor-intensive process. Statistically based experimental designs proved to be valuable tools in optimization culture conditions (Zhang et al., 1996; Ooijkass et al., 1998). One of the advantages of applying multi-factorial experiments is that it considers the interaction between the non-linear natures of the response in short experiments (Gresham and Inamin, 1986). As demonstrated in the present study, Plackett-Burman design was effective in the evaluation of the fermentation medium and their effect on the production of cellulase enzyme by A. flavus. According to the results obtained from this experiment, it was possible to optimize the constituents of the fermentation medium. PlackettBurman design provides indications of how each component tends to affect the response. The conclusions obtained from this experiment were evaluated by a verification experiment in which a predicted optimum culture medium showed increasing in cellulase activity when compared to the basal medium. 
Cellulase production by $A$. flavus that immobilized by entrapment in different gel materials was studied. The gel materials tested, alginate gel polymer and agar were effective for cellulase production. Cellulase activity reached about $7.86 \mathrm{U} / \mathrm{ml}$ when alginate was used, and $8.22 \mathrm{U} / \mathrm{ml}$ when agar was used. But the activity of free cells was higher than that obtained from the entrapped fungal cells in alginate gel materials. Also, the production of cellulase by A. flavus immobilized by adsorption on different porous solid supports was studied. The highest cellulase activity was observed in culture containing luffa pulp as a solid support followed by sponge cubes and pumice particles. The activity was nearly 1.5 fold of that obtained from free cells. Also stainless steel and ceramic particles showed a higher activity than free cells. Only clay pieces showed a slightly lower activity. Some investigators reported enhancement of enzyme production by adsorbed fungal cells on porous support. Humicola lutea 120-5 spores entrapped in polyurethane sponge cubes and cultivated inside the carrier were used for the production of acid proteinases (Aleksieva and Tchorbanov, 1990). Also, the cultivation of A. oryzae cells, which produced alpha-amylase, and A. awamori cells, which produced pectinase, were studied on an immobile solid carrier of porolon (Bliyeva, 1982).

The production of cellulase by immobilized A. flavus was studied. The immobilized cells were reused for seven successive cycles covering a period of 49 days. The reuse of the immobilized mycelia on luffa enhanced the production of the enzyme until third and fourth successive cycle where gradual increase of cellulase activity values was recorded. At fourth cycle, the cellulase activity and protein reached maximum values then gradual decrease was observed in the next reuses. In another study, enhancement of antibiotic biosynthesis with semicontinuous and continuous cultures from immobilized spores of Penicillium utrcae and Penicillium chrysogenum using k-carrageenan beads was reported by (Doe et al., 1984).

Moreover, scanning electron microscope revealed that a relatively condense of masses of fungal mycelia were accumulated on a luffa pulp which reflects the result of high activity of cellulases than in free cells. The good cell adsorption obtained on luffa as a solid support with the simplicity of the immobilization procedure and low cost allows the high yield of cellulase by A. flavus for industrial purposes.

The results of the present investigation collectively indicate the possibility of using free or adsorbed cells of A. flavus for the production of a highly active cellulase, which can be applied in many fields such as food industry, fouls production, paper and pulp industries. The results also indicate the possibility of using different agro-wastes like onion scales as a sole carbon source for production of economically accepted cellulase by A. flavus. 


\section{References}

Aleksieva, P. and Tchorbanov, B. (1990) Production of acid proteinases by Humicola lutea mycelium immobilized in polyurethane sponge. Enzyme Microb. Technol., 12, 994-996.

Bhat, M.K. (2000) Cellulose and related enzymes in biotechnology. Biotechnol. Adv., 18, 355-383.

Bliyeva, R.K. (1982) Semicontinuous cultivation of fungi belonging to the genus Aspergillus and producing hydrolases. Mikrobiolgiya, 51, 945-949.

Castellonos, O.F., Sinitsyn, A.P. and Vlasenko, E.Y. (1995) Comparative evaluation of hydrolytic efficiency toward microcrystalline cellulose of Penicillium and Trichoderma cellulases. Bioresour. Technol., 52, 119 -124.

Chapatwala, K.D., Babu, G.R.V. and Wolfram, J.H. (1993) Screening of encapsulated microbial cells for the degradation of inorganic cyanides. J. Ind. Microbial., 11, 6972 .

Chung, K.C.,Kawai , K., Yashima, S., and Eguchi, Y. (1982) Production of cellulolytic enzyme by Penicillium vemiculosum. Hakko Kagaku., 5, 355-357.

Coral, G., Arikan, B., Nisa, M., Unaldi and Guvenmez, H. (2002) Some properties of crude carboxymethyl cellulase of Aspergillus niger Z10 wild type strain. Turk. J. Biol., 26, 209-213.

Crawford, R.L. (1981) "Lignin biodegradation and transformation". Wiley and Sons, New York, USA.

Doe, Y.M., Costerton, J.W. and Gaucher, G.M. (1984). Semicontinuous and continuous production of antibiotics by immobilized fungal cells. Dev. Ind. Microbiol., 25, 491-503.

Domsch, K. H., Gams, W. and Anderson T. H. (2007) Compendium of soil fungi, IHW, $2^{\text {nd }}$ ed., Verlag, Eching bei Munchen, Germany. pp. 1-672.

Eikmeier, H., Westmeier, F. and Rehm, H.J. (1984) Morphological development of Aspergillus niger immobilized in Ca-alginate and K-carrageenan. Appl. Microbiol. Biotechnol., 19, 53-57.

Farooq, L., Rajoka, M.I. and Malik, K.A. (1994) Saccharification of Leptochloa fusca (Kallar grass straw) using thermostable cellulases. Bioresour. Technol., 50, 107-112.

Gashe, B.A. (1992) Cellulase production and activity by Trichoderma sp. A-001. J. Appl. Bacteriol.,73, 79-82.

Gokhaled, V., Patils, G. and Bastawdke, B. (1991) Optimization of cellulase production by Aspergillus niger NCIM 1207. Appl. Biochem. Biotechnol., 30, 99-109. 
Gresham, R. and Inamin, E. (1986) Nutritional improvement of processes, In: "Manual of Industrial Microbiology and Biotechnology”. Demain, A.L. and Solomon, N.A. (Ed.), ASM, Washington, pp. 41-48.

Hatakka, A.I. (1983) Pretreatment of wheat straw by white-rot fungi for enzymatic saccharification of cellulose. Eur. J. Appl. Microbiol. Biotechnol., 18, 350-357.

Hong, B.J., Broderick, G.A., Koegel, R.G., Shinners, K.J. and Straub, R.J. (1988) Effect of shredding alfalfa on cellulolytic activity, digestibility, rate of passage, and milk production. J. Dairy Sci., 71, 1546.

Howell, J.A. (1978) Enzymatic deactivation during cellulose hydrolysis. Biotechnol. Bioeng., 20, 847-863.

Huang, L. and Forsberg, C.W. (1990) Cellulose digestion and cellulose regulation and distribution in Fibrobacter succinogenes sub sp. succinogenes S85. Appl. Environ. Microbiol., 56, 1221.

Jungebloud, A., Bohle, K., Göcke, Y., Cordes, C., Horn, H. and Hempel, D.C. (2007) Quantification of product-specific gene expression in biopellets of Aspergillus niger with real-time PCR. Enz. Microb. Technol., 40, 653-660.

Klemn, D., Heublein, B., Fink, H. P. and Bohn, A. (2005) Cellulose: Fascinating biopolymer and sustainable raw material. Angew. Chem. Int. Ed., 44, 3358-3393.

Knapp, J.S., Vantoch-Wood, E.J. and Zhang, F. (2001) Wood-rotting fungi for decolorization, In: "Fungi in Bioremediation". Cambridge University Press, Gadd, G.M. (Ed.), Cambridge, UK, p. 260.

Lakshmikant, K. and Mathur, S.N. (1990) "Cellulolytic activities of Chaetomium globosum on different substrates. World J. Microb. Biotechnol., 6, 23-26.

Lan, T.Q., Wei, D., Yang, S.T. and Liu, X. (2013) Enhanced_cellulase_production by Trichoderma viride in a rotating fibrous bed bioreactor. Bioresour. Technol., 133, 175-182.

Lee, Y. H., Lee, C. W. and Changh, N. (1989). Citric acid production by Aspergillus niger immobilized on polyurethane foam. Appl. Microbiol. Biotechnol., 30, 141-143.

Li, Z.Q., Liu, B.R., Zeng, W.H., Xiao, W.L., Li, Q.J. and Zhong, J.H. (2013) Character of cellulase activity in the guts of flagellate-free termites with different feeding habits. J. Insect Sci., 13, 1-8.

Lowry, O.H., Rosebrough, N.H., Farr, A.L. and Randall, R.J. (1951) Protein measurement with the folin phenol reagent. J. Biol. Chem., 193, 265-275.

Lynd, L.R., Weimer, P.J., van Zyl, W.H. and Pretorius, I.S. (2002) Microbial cellulose utilization: fundamentals and biotechnology. Microbiol. Mol. Biol. Rev., 66, 506-577. 
Ma, D.B., Gao, P.J. and Wang, Z.N. (1990) Preliminary studies on the mechanism of cellulase formation by Trichoderma pseudokoningii S-38. Enz. Microb. Technol., 12, 631-635.

Mandels, M. and Reese, E.T. (1960) Induction of cellulase in fungi by cellobiose. $J$. Bacteriol., 79, 816-826.

Markham, P. and Bazin, M. J. (1991) Decomposition of cellulose by fungi, In: "Handbook of Applied Mycology”, Arora D.K., B. Rai, B., Mukerji, K.G.and Knudsen G.R. (Ed.), vol. 1. pp. 379-424.

Miller, G.L. (1959) Use of dinitrosalicylic acid reagent for determination of reducing sugar. Anal. Chem., 31, 426-428.

Ojumu, T.V., Solomon, B.O., Betiku, E., Layokun, S.K. and Amigun, B. (2003) Cellulase production by Aspergillus flavus Linn isolate NSPR 101 fermented in sawdust, bagasse and corncorb. Afr. J. Biotechnol., 2, 150-152.

Okeke, B.C. and Obi, S.K.C. (1995) Saccharification of agro wastes materials by fungal cellulases and hemicellulases. Bioresource Technol., 51, 23-27.

Okemoto, K., Uekita, T., Tsumuraya, Y., Hashimoto, Y. and Kasama, T. (2003) Purification and characterization of an endo-beta- $(1 \rightarrow 6)$-galactanase from Trichoderma viride. Carbohydr. Res., 338, 219-230.

Oksanen, T., Pere, J., Paavilainen, L., Buchert , J. and Viikari, L. (2000). Treatment of recycled Kraft pulps with T. ressei hemicellulases and cellulases. J. Biotechnol., 78, 39-48.

Onsori, H., Zamani, M.R., Motallebi, M. and Zarghami, N. (2005) Identification of over producer strain of endo- $\beta$-1,4-glucanase in Aspergillus species: Characterization of crude carboxymethyl cellulase. Afr. J. Biotechnol., 4, 26-30.

Ooijkass, L.L., Wilkinson, E.C., Tramper, J. and Buiterlaar, R.M. (1998) Medium optimization for spore production of Conithyium minitans using statistically-based experimental designs. Biotechnol. Bioeng., 64, 92-100.

Orteg, M. (1990) Production of extracellular cellulolytic enzymes by Fusarium oxysporum f. sp. lycopersici. Texas J. Sci., 42, 405-409.

Plackett, A.R.L. and Burman, J.P. (1946) The design of optimum multifactorial experiments. Biometrica, 33, 305-325.

Saddler, J.N., Hogan C.M., Louis-Seize, G. and Yu, E. (1984) Factors affecting cellulase production and the efficiency of cellulose hydrolysis. In: Hasnain, S., Lamptey, J. and Moo-Young, M. (Ed.), Proceeding of the Firest Bioenergy Specialist Meeting on Biotechnology. pp. 135-145.

Singh, A., Yadav, R.D., Kaur, A. and Mahajan, R. (2012) An ecofriendly cost effective enzymatic methodology for deinking of school waste paper. Bioresour. Technol., 120, 322-327. 
Solomon, B.O., Amigun, B., Betiku, E., Ojumu, T.V. and Layokun, S.K. (1999) Optimization of Cellulase Production by Aspergillus flavus Linn Isolate NSPR 101 Grown on Bagasse. JNSChE., 16, 61-68.

Vlasenko, E.Y., Castellanos, O.F. and Sinitsyn, A.P. (1993) Susceptibility of different cellulose containing materials to hydrolysis by cellulolytic enzymes. Prikl. Biokhim. Mikrobiol., 29, 834-843.

Yazdi, M.T., Wood ward, J.R. and Radford, A. (1990) The cellulose complex of Neurospora crassa: Activity, stability and release. J. Gen. Microbial., 136, 13131319.

Zhang, J., Marcin, C., Shifflet, M.A., Salmon, P., Brix, T., Greasham, R., Buckland, B. and Chartrain, M. (1996) Development of a defined medium fermentation process for physotigmine production by Streptomyces griseofuscus. Appl. Microbiol. Biotechnol., 44, 568-575.

(Received 19/9/2013;

accepted $1 / 1 / 2014$ 


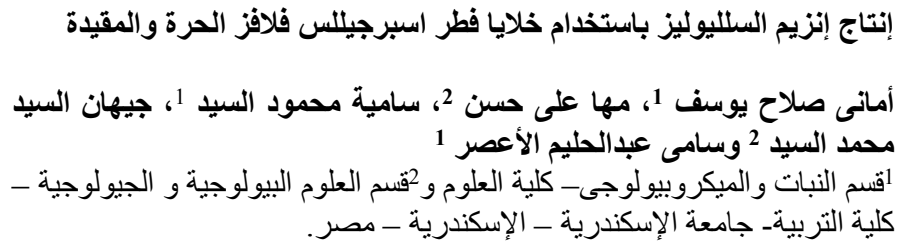

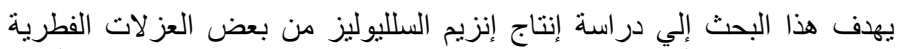

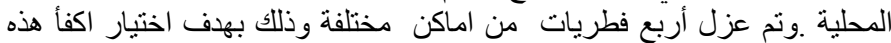

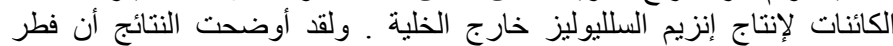

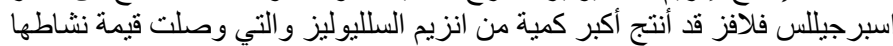

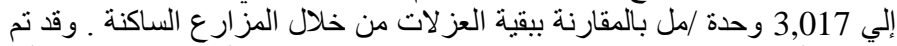

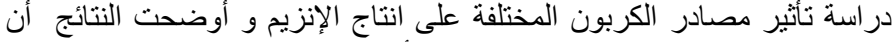

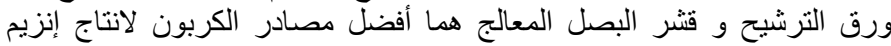

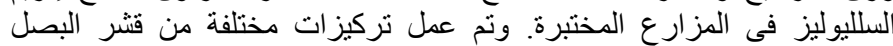

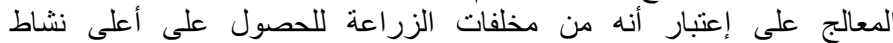

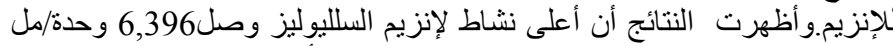

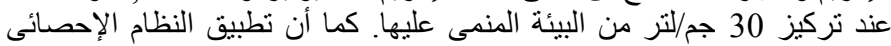

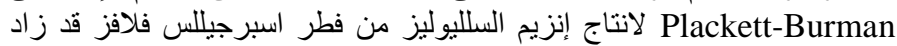

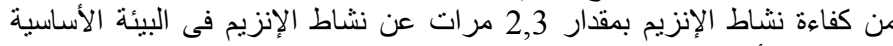

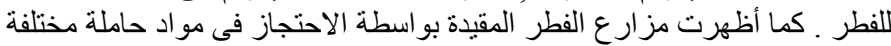

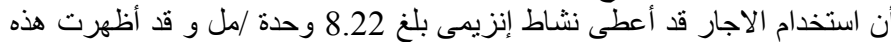

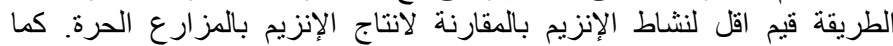

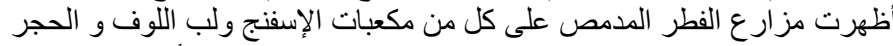

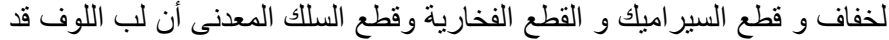

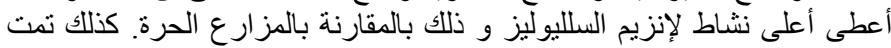

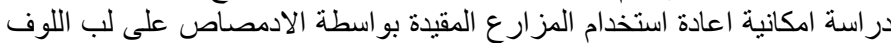

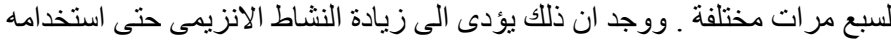

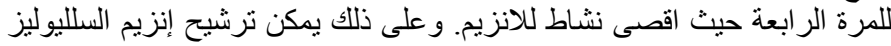

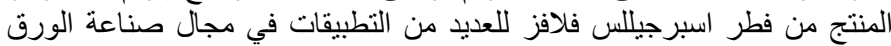

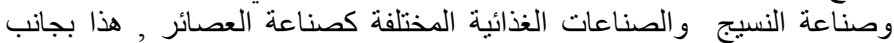
استخدامه فى المجال الدو ائى. 